\title{
Evaluating Company Failure in Malaysia Using Financial Ratios and Logistic Regression
}

\author{
Ben Chin Fook Yap \\ Senior Lecturer, Universiti Tun Abdul Razak \\ E-mail: benyap@unirazak.edu.my \\ Dr. Shanmugam Munuswamy \\ Associate Professor, Universiti Tun Abdul Razak \\ Dr. Zulkifflee Bin Mohamed \\ Assistant Professor, Universiti Tun Abdul Razak
}

Received: May 2, $2012 \quad$ Accepted: May 14, $2012 \quad$ Published: June 1, 2012
doi:10.5296/ajfa.v4i1.1752 $\quad$ URL: http://dx.doi.org/10.5296/ajfa.v4i1.1752

\begin{abstract}
This paper investigates the ability of logistic regression in anticipating corporate failures in Malaysia over a ten year period covering the economic cycles of boom, the Asian financial crisis of 1997 and economic recovery. 64 companies were analyzed with an initial 16 financial ratios. A strong logit model was developed with four ratios found to be significant in its predictive power and classification results showed very high average accuracy rates of $88 \%$ and $90 \%$ for the analysis and the hold-out samples respectively and for each of the five years preceding the actual failure. This study also showed it does not need many ratios to be able to anticipate potential company failures and that even with more advanced statistical models used recently, logistic regression is still a very effective and reliable statistical tool.
\end{abstract}

Keywords: Financial ratios, Company failures, Failure predictions, Logistic regression. JEL Classification Codes: G33, C39, M41 


\section{Introduction}

An economic downturn like the 1997-98 Asian financial crisis resulted in a sharp decline in the value of the Malaysian Ringgit followed by drastic drops in stock prices that dampened business confidence and increased company bankruptcies. During normal times, however, business failures are more likely to be caused by falling profits or losses for several years in succession, excessive debts, insufficient working capital, managerial errors and misjudgments, though management frauds have surfaced more frequently and involving large multinationals recently.

Over the years, various analytical techniques such as multiple discriminant analysis, logistic regression, linear probability models and artificial neural network models, have been used to predict potential company failures and these previous studies have found that they are effective and reasonably accurate though some of the claims made may seem not as credible when tested over time and with different samples and populations and in different sectors. However, financial ratios and bankruptcy prediction models are useful and helpful as attested by the continuing interests and continuing usage of them by a wide range of managers, analysts and other professionals in commerce, finance and industry.

Companies in Malaysia do not have as long a history as those in the Western countries and their sizes are, for most of the companies, not as large. In addition, their access to funds and capital are not as easily available compared to the more developed countries. The development of the capital market in Malaysia is still at its early stages compared to advanced markets in the West. Although the government has always been stressing the importance of good corporate governance, Malaysia has not been immune to corporate collapses and scandals. Therefore, the selection of financial ratios and the predictive models and their statistical techniques used in researches done elsewhere may not be as applicable or as reliable and accurate as when they are applied to the Malaysian companies.

Many investigations and studies on company failure predictions have been carried out in developed countries such as by Altman (1968), Deakin (1972) and Ohlson (1990) in the US, Green (1978), Wood \& Piesse (1987) and Inman (1991) in the UK, and Gepp \& Kumar (2008) and Jones \& Hensher (2004) in Australia. These countries have longer trading and commercial histories with more stringent company law provisions and stronger law enforcements and penalties.

Studies on company defaults, failure and bankruptcy prediction on Malaysian companies only started in 2001 with studies done by (i) Mohamed et al. (2001) using the logit method with correct classification of $81 \%$ and $74 \%$ for the analysis and holdout samples respectively, (ii) Zulkarnain et.al. (2001) using MDA with correct classification of $91 \%$ and $71 \%$ for the analysis and holdout samples respective, (iii) Low, Nor \& Yatim (2001) using the logit model with correct classification of $82 \%$ and $90 \%$ for the analysis and holdout samples respectively and (iv) Adiana et.al. (2008) using the hazard model with correct classification of $83 \%$ and $86 \%$ for the analysis and holdout samples respectively. Many of the previous studies on bankruptcy prediction do not have the same consensus on the term "failure" or bankruptcy. Definitions from different studies vary significantly and arbitrarily. Is it loan interest defaults, 
bond interest defaults, inability to pay preference dividends, inability to pay liabilities when due or when a creditor file for liquidation and bankruptcy?

In their study, Poston et. al. (1994) considered that a company is in financial distress if it has two or more consecutive years of operating losses or a current ratio of less than 1.0 as at the end of any single fiscal year or a negative balance in the Retained Earnings account as at the end of any single fiscal year. According to them, meeting any one of the above criteria would be considered a distress situation. Flagg, Giroux \& Wiggins (1991) identified four potential failure events, namely reductions in dividends, "Going concern" qualified audit opinion, troubled debt restructuring and violations of debt covenants.

For this study, the failed companies analyzed are either (i) classified by Bursa Malaysia (formerly the Kuala Lumpur Stock Exchange) as falling either under one of the Practice Notes (PNs) namely PN4, PN10 or PN17 or (ii) they have applied to the Court under Section 176 of the Companies Act 1965, for a Scheme of Arrangement. The main reasons for companies being designated as PN companies by Bursa Malaysia are mainly because of deficits in their shareholders funds where their financial conditions do not justify continued trading and/or listing in the stock exchange. These companies are given certain time to regularize their financial position or take actions that is necessary to release themselves from those criteria that trigger the specific PN classifications stated above. For companies that have applied for Section 176 protection, an order is given by the High Court to stay any proceedings against the companies whilst the scheme is pending.

Although many bankruptcy and default prediction models have been developed, it is of utmost importance that we first test for the feasibility of models used for Malaysian companies with different company sizes and under the present market and economic conditions. It is also important that we can produce a modified model with different variables, (after reviewing the few studies carried out in Malaysia as mentioned above), to identify companies that has a high probability of failure from those that are highly unlikely to fail.

This study is based on companies in the manufacturing sector being officially classified as consumer and industrial product companies. Companies in the trading, services and property and construction sectors are not included as they have different assets and financing requirements compared to companies involved in manufacturing. For similar reasons, companies in the financial and banking sectors are also excluded.

Company collapses and bankruptcies affect stakeholders including shareholders, suppliers, creditors, customers, employees and management itself. Incidences of company failures, especially large corporate entities that employ large number of people can significantly affect the livelihood of many people and the economy of the locality where the company is located. Shareholders and investors can suffer huge economic losses as they are among the last group of interested parties who would be paid off in any liquidations and winding-ups. In cases of negligence or fraud, managers and office bearers can be subject to severe penalties including heavy fines, convictions and jails. If impending company failures are not detected early or the collapse has already happened, it can mean that these companies may not be disclosing truthful and adequate information about their financial health. It can also imply that the accounting 
standards and other regulatory and legal requirements may not be enough to ensure proper and fair disclosures. It is obvious that any additional tools or improved models for detecting signs of companies in distress would be most helpful. Finance managers and controllers trained in the analysis and evaluation of the financial health of companies can take corrective and preventive measures to prevent failure in their own companies. Institutional investors and fund managers who manage large investment portfolios can improve their performances and generate higher returns for their clients if they can distinguish the weak companies from the healthy ones.

The objective of this study is to develop a failure prediction model using logistic regression and a different group of financial/accounting ratios to obtain a much higher correct classification rates for failed and non-failed companies in Malaysia under local financial, market and economic conditions for each of the five years preceding the date of the actual company failure. Although, more advanced statistical techniques such as artificial neural networks and recursive partitioned decision trees have been used, results obtained from these later methods have outperformed other statistical classification techniques as found by the study by Frydma, Altman \& Kao1985).

\section{Brief Review of Previous Studies}

According to Green (1978), the earliest studies on the financial health of companies were univariate in nature starting with works by FitzPatrick and Winakor \& Smith in the 1930s and Mervin in 1942. The most well-known univariate model is probably the 1966 study by Beaver, which from then on, has started many other company failure prediction analyses using other statistical techniques.

The univariate approach was criticized for various weaknesses. Altman (1968) stated that one of the main shortcomings of using the univariate method is that the ratios are not allowed to interact with one another as each ratio is examined separately, in isolation from the other ratios. Morris (1998) illustrated with the example that while low profitability may be one signal of financial distress, it may not necessarily be fatal if a business has a strong liquidity position, and likewise, a company that is profitable but which has low reserves of liquid assets is potentially vulnerable if there should be an unexpected setback. Thus using a single variable to determine a financial distress situation is risky.

From some of the shortcomings of univariate analyses in evaluating ratios individually and independently of each other, it seems obvious that there may be advantages in developing models which simultaneously examine a number of key characteristics, such as profitability, short and long term liquidity, gearing and so on. In attempts to formulate models that take into account the simultaneous interaction between variables, researchers have devised, and come out with newer models mostly based on multiple regression statistical techniques such as multiple discriminant analysis by Altman (1968) and Koh \& Killough (1990) and logistic regression by Ohlson (1980), Gilbert, Menon \& Schwartz (1990) and Lin \& Piesse (2004).

Another popular modeling technique is artificial neural network which uses a non-linear approach and gives a computer system an amazing capacity to actually learn from input data. 
Artificial neural networks (ANNs) have provided solutions to problems normally requiring human observation and thought processes including Speech and Pattern Recognition, Credit Rating and Bankruptcy Forecasting. Studies on company failure predictions using ANNs have been carried out by Dorsey, Edminster \& Johnson (1995) and Pramodh \& Ravi (2007).

Some other well-known modeling techniques that have been developed and used for corporate failure predictions include Balance Sheet Decomposition model by Lev (1973), cash based models by Casey \& Bartczak (1985) and Aziz, Emanuel \& Lawson (1998), the hazard model by Shumway (2001) and the survival analysis model by Gepp \& Kumar (2008). However, not all the above methodologies and techniques are popular and some have not been commonly used in distress studies.

In almost all bankruptcy studies, financial measures and financial ratios play the dominant role in almost all the variables used as predictors attesting to the fact that ratios do contribute substantially and immeasurably to understanding company financial performance and future financial status. Deakin (1972) showed considerable evidence that investors use financial ratios to study and analyze published financial data, implying its usefulness consistent with the accounting and finance literature which asserts that ratio analysis is useful to investors. Gardiner (1995) in a review of some of the most important financial ratios stated that ratio analysis is universally recognized as a powerful financial tool and are used by investors when deciding between choices of alternative investments. His study also confirmed that financial ratios are used by banks and other lenders before decisions are made on whether to grant certain loans, by auditors when they conduct analytical reviews of their clients as well as by companies when assessing the creditworthiness of their debtors.

\section{Methodology}

\subsection{Selection of Variables}

Karels \& Prakash (1987) suggested a careful selection of ratios to be used in the development of a bankruptcy prediction model, as the choice of ratios can affect the prediction accuracy of the model. The choice of ratios used may have to be different for companies in different industries. Gombola \& Ketz (1983) found that ratios in the retail and manufacturing industries are at their extreme in their characteristics and that companies in other industries seems to fall in-between these extreme ends.

Shivaswamy \& Holban (1993) identified 19 ratios as important in analyzing retail companies and 14 ratios considered important in analyzing manufacturing companies. In their study, they found that bankers use one set of ratios to evaluate retail firms and another set of ratios when appraising manufacturers. Bankers found that liquidity and activity ratio groups were significantly more important for retailers than for manufacturers while the profitability and leverage ratio groups were equally important for both groups.

Koh \& Killough (1986) found that it is not necessary to have a large number of ratios to predict business failures and all that is needed is a set of dominant ratios derived from a larger set of related ratios. In this study, 16 ratios (Table 1) were selected among the many that had been used in previous studies. These ratios were selected to evaluate profitability, 
efficiency, liquidity, and solvency and leverage. The selection and the choice of ratios were based on two main conditions. The ratios have been frequently used in past studies and that the ratios have been shown to perform well in past studies. Table 1 also shows some of the earlier studies that have also used these ratios in their analyses.

Table 1. The Sixteen Ratios Selected in This Study

\begin{tabular}{|c|c|c|c|c|}
\hline & Descriptions & Initials & Measure & Used in past studies \\
\hline 1 & Net Income to Total Assets & NITA & Profitability & $\begin{array}{l}\text { Ohlson (1980) } \\
\text { Flagg (1991) } \\
\text { Adiana (2008) }\end{array}$ \\
\hline 2 & Retained Earnings to Total Assets & RETA & Profitability & $\begin{array}{l}\text { Altman (1968) } \\
\text { Gilbert (1990) } \\
\text { Flagg (1991) }\end{array}$ \\
\hline 3 & $\begin{array}{l}\text { Earnings Before Interest and Tax to } \\
\text { Total assets }\end{array}$ & EBITTA & Profitability & $\begin{array}{l}\text { Altman (1968) } \\
\text { Gombola (1983) } \\
\text { Karels (1987) }\end{array}$ \\
\hline 4 & Net Income to Sales & NIS & Profitability & $\begin{array}{l}\text { Gombola (1983) } \\
\text { Mutchler (1985) } \\
\text { Karels (1987) }\end{array}$ \\
\hline 5 & $\begin{array}{l}\text { Current Asset to Current Liabilities } \\
\text { (Current ratio) }\end{array}$ & CACL & Liquidity & $\begin{array}{l}\text { Beaver (1966) } \\
\text { Altman (1977) } \\
\text { Gilbert (1990) } \\
\text { Zulkarnain (2001) }\end{array}$ \\
\hline 6 & Working capital to Total Assets & WCTA & Liquidity & $\begin{array}{l}\text { Beaver (1966) } \\
\text { Altman (1968) } \\
\text { Ohlson (1980) } \\
\text { Mossman (1998) } \\
\text { Jones (2004) }\end{array}$ \\
\hline 7 & Market value Equity to Total Debt & METD & Liquidity & $\begin{array}{l}\text { Altman (1977) } \\
\text { Mossman (1998) } \\
\text { Zulkarnain (2001) }\end{array}$ \\
\hline 8 & Cash Flow to Total Debts & CFTD & Liquidity & $\begin{array}{l}\text { Beaver (1966) } \\
\text { Casey (1985) } \\
\text { Gilbert (1990) }\end{array}$ \\
\hline 9 & Cash to Sales & $\mathrm{CS}$ & Liquidity & $\begin{array}{l}\text { Deakin (1972) } \\
\text { Karels (1987) }\end{array}$ \\
\hline 10 & Current Assets to Total Assets & CATA & Liquidity & $\begin{array}{l}\text { Deakin (1972) } \\
\text { Gilbert (1990) }\end{array}$ \\
\hline 11 & Working Capital to Sales & WCS & Liquidity & $\begin{array}{l}\text { Deakin (1972) } \\
\text { Karels (1987) }\end{array}$ \\
\hline 12 & Cash to Current Liabilities & $\mathrm{CCL}$ & Liquidity & $\begin{array}{l}\text { Deakin (1972) } \\
\text { Zavgren (1985) }\end{array}$ \\
\hline
\end{tabular}




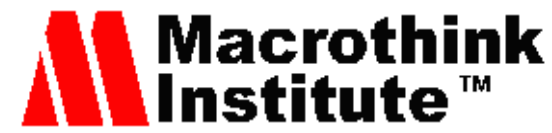

Asian Journal of Finance \& Accounting

ISSN 1946-052X 2012, Vol. 4, No. 1

\begin{tabular}{|l|l|l|l|l|}
\hline 13 & Total Debts to Total Assets & TDTA & Solvency & $\begin{array}{l}\text { Beaver (1966) } \\
\text { Ohlson (1980) } \\
\text { Zulkarnain (2001) }\end{array}$ \\
\hline 14 & Funds Flow to Total Liabilities & FFTL & Liquidity & Ohlson (1980) \\
\hline 15 & Debtors Turnover & Debtor & Efficiency & $\begin{array}{l}\text { Gombola (1983) } \\
\text { Zavgren (1985) }\end{array}$ \\
\hline 16 & Sales to Total Assets & STA & Efficiency & $\begin{array}{l}\text { Gilbert (1990) } \\
\text { Mohamed (2001) }\end{array}$ \\
\hline
\end{tabular}

\subsection{Data collection and Sample}

Financial data from the annual reports of the selected failed and non-failed public companies listed in Bursa Malaysia were extracted. The data collected were for a ten-year period starting 1996 until the end 2005. Data of the selected failed and non-failed companies were obtained for five years preceding the actual failure. The "first year preceding failure" is defined as that year included in the most recent financial statement prior to the date that the company failed, i.e., if the company failed in 2006 , then the last financial statement data used would be the one prepared for the most recent year before failure. The second year prior to failure would be the financial year preceding the first year. If the first year prior to failure was 31 December 2006, then data for the preceding 4 years ending 31 December 2002 to 31 December 2005 would be used.

Beaver (1966), Altman (1968), Lev (1973), Letza, Kalupa \& Kowalski (2003) and Aziz, Emanuel \& Lawson (1988) has all used matched pair samples of failed and non-failed companies. The paired-sample design is one way of compensating for the effects of industry and asset size differences. Companies with the same financial ratios but with different asset sizes may have different probabilities of failure. It is logical that a larger company with a larger asset base will have a lower probability of failure even if the ratios of the two firms are identical.

A total of 64 companies are divided equally into half, comprising 32 failed companies and 32 non-failed companies. For each failed company, a non-failed company in the same industry and with the closest asset size is selected. The financial statements of the non-failed companies are obtained for the same fiscal years as those of the failed companies, that is, if the failed company has a financial year ending 31 Dec 2006, the non-failed company would be chosen with financial statements ending in the same year.

Each of the above group will be further divided into half. One half will comprise of 16 failed companies and 16 non-failed companies to be used for the development of the model (the analysis sample) and the other half of 16 failed and 16 non-failed companies will be used as secondary or validation sample (the holdout sample).

\subsection{Logistic Regression}

Logit analysis tries to calculate a probability, based on a probability distribution. Like discriminant analysis, it weighs the independent variables and assigns a score in the form of 
failure probability to each company in the sample. This statistical procedure does not just group a firm to either fail or healthy based purely on financial factors as there are other external factors to consider in analyzing risks and defaults, such as unexpected random events, macro-economic factors and new governmental rules and regulations. The advantages of logistic regression analysis are that it does not assume multivariate normality and equal covariance matrices.

The logit model utilizes the coefficients of the independent variables to predict the probability of failed or non-failed dependent variable. The technique weights the independent variables and creates a score for each company in order to classify it as failed or non-failed. The function considered in logistic regression is called the logistic function.

Based on Ohlson (1980) seminal study, the logistic model is stated as:

$$
\int((\beta)) \equiv \sum \log P\left(X_{i}, \beta\right)+\sum \log \left(1-P\left(X_{i}, \beta\right)\right.
$$

$i \in s_{1} i \in s_{2}$

where: $\mathrm{X}_{\mathrm{i}} \quad$ = vector of predictors for the i observation

$\beta=$ vector of unknown parameters

$P \quad=$ some probability function, $0 \leq \mathrm{P} \leq 1$

$P\left(X_{i}, \beta\right)=$ the probability of bankruptcy for any given $X_{i}$ and $\beta$

Measures of goodness of fit would be determined through Pearson's and Deviance's Chi-Square values and the significance of the variables used. If the p-value is $>0.05$ then the value is not significant and the model fit is good.

A likelihood ratio test is used to see if the variables included in the final model are significant in explaining some of the variability in the data. The Chi-Square statistic is the difference in -2 Log Likelihood (-2LL) between the final model and a reduced model. The reduced model is formed by omitting an effect from the final model. The null hypothesis is that all parameters of that effect are 0 . This test is comparable to the overall $\mathrm{F}$ test for regression analysis.

In multiple regressions, $\mathrm{R}^{2}$ is an intuitive measure of how well the model predicts the values of the dependent variables. However, in logistic regression, there are no similar measures that are easily interpreted. The Psuedo RSquare (Cox and Snell and Nagelkerke) are attempts to quantify the proportion of explained variation in the dependent variable. The Cox and Snell measures are usually $<1.0$ and are difficult to interpret. The Nagelkerke's measure ranges from 0 to 1 and values are normally higher than Cox and Snell. This measure is the most reported $\mathrm{R}^{2}$ for logistic regression (Norusis, 2005). The higher the values, the better the model fit.

To reduce the large number of financial ratios, numerous logistic runs on the SPSS are performed using different combination of ratios. For each logit function constructed, the model fit will be assessed on how strong is the function, how well it discriminates and checking the classification matrices for predictive accuracy not just for the failed companies 
but also for the non-failed companies as well. The model accepted has to have a good fit and that the multicollinearity level is acceptable. The companies are classified as failed or non-failed according to their probability estimates. This would be shown in a classification table where the number of failed companies and non-failed companies are accordingly classified.

\section{Findings and Discussion}

After numerous logistic runs, one logistic regression function was estimated. The logistic function constructed was based on the log transformed values for each ratio and has a $50 \%$ probability of group membership, that is, failed and non-failed.

Four ratios were found to have significant discriminating power in evaluating failure prediction. They are Cash Flow to Total Debts (CFTD), Total Debts to Total Assets (TDTA), Retained Earnings to Total Assets (RETA) and Cash to Current Liabilities (CCL). Of these four ratios, two of the ratios measure liquidity, one measure profitability and one measure solvency.

Hossari \& Rahman (2005) identified 48 ratios most popularly used in past studies. Of the top 10 ratios that are most popular, 4 measures liquidity, another 4 measures profitablilty and the remaining 2 ratios measures solvency.

The breakdown of these four ratios identified in this study in terms of what they measure and how they compare to the 10 most popular financial ratios found to be useful in past studies by Hossari \& Rahman (2005) as mentioned earlier are shown in Table 2 below. The results showed that those financial ratios that measure liquidity are the most effective in their discriminating power.

Table 2. Comparisons of Financial Ratios Selected and what they Measure compared to past studies

\begin{tabular}{|l|l|l|l|}
\hline Present Study & Percentage & Past Studies & Percentage \\
\hline Liquidity & $50 \%$ & Liquidity & $40 \%$ \\
\hline Profitability & $25 \%$ & Profitability & $40 \%$ \\
\hline Solvency & $25 \%$ & Solvency & $20 \%$ \\
\hline
\end{tabular}

The classification results for the analysis sample as shown Table 3 below, showed an average correct classification for the failed and non-failed companies of $89 \%$ and $88 \%$ respectively for the five years preceding actual failure. The results also showed that the highest accuracy rate is for the first year preceding failure at $94 \%$ for both the failed and non-failed companies. . It is generally accepted that the discriminating power of any model that is developed will lose its predictive accuracy the further away the time period is from its actual failure. As the results show, even in Years 4 and 5 preceding failure, the results are very impressive with an average correct classification of $84 \%$ and $88 \%$ respectively. 
Table 3. Classification Results: Analysis Sample

\begin{tabular}{|l|c|c|c|c|c|c|}
\hline Classification results (\%) & Year & Year & Year & Year & Year & Av. \\
& 1 & 2 & 3 & 4 & 5 & 5 Yrs \\
\hline Analysis Sample - Fail & $\mathbf{9 4}$ & 88 & 88 & 81 & 94 & $\mathbf{8 9}$ \\
\hline Non-Fail & $\mathbf{9 4}$ & 88 & 88 & 88 & 81 & $\mathbf{8 8}$ \\
\hline Average & 94 & 88 & 88 & $\mathbf{8 4}$ & $\mathbf{8 8}$ & 88 \\
\hline
\end{tabular}

The results for the holdout sample (Table 4) showed even slightly better results compared to the analysis sample giving an average correct classification of $92 \%$ and $89 \%$ for the failed and non-failed companies respectively for the five years. The highest average correct classification results are $94 \%$ for Year 2 and Year 5 before the actual failure.

Table 4. Classification Results: Holdout Sample

\begin{tabular}{|cl|c|c|c|c|c|c|}
\hline Classification results (\%) & Year & Year & Year & Year & Year & Av. \\
& & 1 & 2 & 3 & 4 & 5 & 5 Yrs \\
\hline Holdout Sample - Fail & 88 & 94 & 88 & 88 & 100 & $\mathbf{9 2}$ \\
\hline - Non-Fail & 94 & 94 & 88 & 81 & 88 & $\mathbf{8 9}$ \\
\hline- & Average & 91 & $\mathbf{9 4}$ & 88 & 84 & $\mathbf{9 4}$ & 90 \\
\hline
\end{tabular}

For both the analysis and holdout samples, the results are striking in that a consistently high accuracy has been achieved for both the failed and non-failed companies and for each of the five years. It seems that our 'hit' rate surpasses some of the past studies, although the sample size is small." One of the most well known studies using logistic regression was by Ohlson and his findings for the three years preceding failure showed average accuracy rates of $88 \%$ and $83 \%$ for the failed and non-failed companies. The Malaysian studies using the logistic regression methods in fact showed a much lower average prediction accuracy rates (Mohammed, Li \& Sanda (2001) with $81 \%$ and $75 \%$ for the analysis and holdout samples respectively and Low, Nor \& Yatim (2001) with $82 \%$ and $90 \%$ for the analysis and holdout samples respectively).

The measure of the overall model fit as indicated by the $-2 \log$ likelihood value (-2LL), the Chi-Square Goodness-of-Fit tests, the Pearson and Deviance Chi-Square goodness of fit as well as the Pseudo $\mathrm{R}^{2}$ measures are as tabulated in Table 5 for the analysis sample and Table 6 for the holdout sample. 
Table 5. Logistic Function Model Fit Results - Analysis Sample

\begin{tabular}{|c|c|c|c|c|c|}
\hline & Year 1 & Year 2 & Year 3 & Year4 & Year 5 \\
\hline -2LL Final & 4.961 & 12.701 & 18.839 & 22.268 & 21.648 \\
\hline Chi-Square & 39.401 & 31.661 & 25.523 & 22.094 & 22.714 \\
\hline Significance & 0.000 & 0.000 & 0.000 & 0.000 & 0.000 \\
\hline \multicolumn{6}{|l|}{ Goodness-of-Fit } \\
\hline Pearson Chi-Square & 4.289 & 14.544 & 19.373 & 29.648 & 40.643 \\
\hline Significance & 1.000 & 0.975 & 0.858 & 0.330 & 0.045 \\
\hline Deviance Chi-Square & 4.961 & 12.701 & 18.839 & 22.268 & 21.648 \\
\hline Significance & 1.000 & 0.991 & 0.876 & 0.724 & 0.755 \\
\hline \multicolumn{6}{|l|}{ Pseudo-R ${ }^{2}$} \\
\hline Cox \& Snell & 0.708 & 0.628 & 0.550 & 0.499 & 0.508 \\
\hline Nagelkerke & 0.944 & 0.838 & 0.773 & 0.665 & 0.678 \\
\hline
\end{tabular}

For the analysis sample (Table 5) and for all the five years, the values of the -2LL are low indicating a well fitting logit model. The relatively high model chi-square values with significant $p$-values ( $p$-value of $<0.05$ ), showed that the independent variables entered in the logit construct significantly impact the dependant variables.

The Pearson Chi-square goodness of fit tests for Years 1 to 4 before actual failure showed p-values of $>0.05$ indicating that they are not significant and the overall model fit is good. For Year 5 before actual failure the p-value is 0.045 which is significant but the p-value for the Deviance Chi-square for the same year is not significant at 0.755 . Together with the acceptable -2LL and the Pseudo- $\mathrm{R}^{2}$ results, it may help explain why the correct classification rate for Year 5 before actual failure is still very high at $91 \%$ and $84 \%$ for the failed and non-failed companies respectively. This can be interpreted that the overall measure of fit is still very good.

The Cox \& Snell and Nagelkerke Pseudo- $\mathrm{R}^{2}$ results showed values that are reasonably high indicating that an acceptable proportion of variation in the dependent variable is explained by the independent variables. Though this measure is similar to the regression analysis's $\mathrm{R}^{2}$, the values calculated for logistic regression are typically smaller than what is seen for linear regression models (Norusis 2005). 
Table 6. Logistic Function Model Fit Results - Holdout Sample

\begin{tabular}{|c|c|c|c|c|c|}
\hline & Year 1 & Year 2 & Year 3 & Year4 & Year 5 \\
\hline -2LL Final & 21.905 & 9.083 & 14.631 & 26.123 & 11.583 \\
\hline Chi-Square & 22.457 & 35.278 & 29.730 & 18.238 & 32.778 \\
\hline Significance & 0.000 & 0.000 & 0.000 & 0.001 & 0.000 \\
\hline \multicolumn{6}{|l|}{ Goodness-of-Fit } \\
\hline Pearson Chi-Square & 39.142 & 8.966 & 12.669 & 25.020 & 16.881 \\
\hline Significance & 0.062 & 1.000 & 0.991 & 0.573 & 0.934 \\
\hline Deviance Chi-Square & 21.905 & 9.083 & 14.631 & 26.123 & 11.583 \\
\hline Significance & 0.742 & 1.000 & 0.974 & 0.512 & 0.996 \\
\hline \multicolumn{6}{|l|}{ Pseudo-R ${ }^{2}$} \\
\hline Cox \& Snell & 0.504 & 0.668 & 0.605 & 0.434 & 0.641 \\
\hline Nagelkerke & 0.672 & 0.891 & 0.807 & 0.579 & 0.855 \\
\hline
\end{tabular}

For the holdout sample (Table 6), the -2LL, the Pearson and Deviance Chi-square as well as the Pseudo- $\mathrm{R}^{2}$ measures all indicated that the logit model developed has a good model fit which has also resulted in the high average correct classifications of between $89 \%$ and $92 \%$ for the failed and non-failed companies as mentioned earlier. The Pearson and Deviance Chi-Square p-values are not significant for each of the five years and these values also indicate good model fit.

The findings showed that with just four financial ratios (from an original 16) used as independent variables in a logistic regression model, they can predict and anticipate corporate failures with very high correct classifications for each of the five years preceding the actual corporate failure.

\section{Conclusion}

The purpose of this study is to examine the ability of logistic regression in anticipating corporate failures in Malaysia. Over a ten year period covering the economic cycles of boom, bust and recovery, 64 companies were analyzed using 16 financial ratios. A strong logit model was developed with four ratios found to be significant in their discriminating abilities. For the five years preceding the actual failure, the results showed average correct classification rates of between $88 \%$ and $90 \%$ for the analysis and holdout samples respectively. The results are especially impressive for Year 4 and Year 5 preceding the actual failure with $84 \%$ and $88 \%$ for the analysis sample and $84 \%$ and $90 \%$ for the holdout sample. Not many past studies have managed to achieve such high rates of success the further away the time period is from the actual failure. The results also revealed that financial ratios that measure liquidity are the most significant in their discriminating power on whether a company is successful or will become financially distressed and eventually end in failure and bankruptcy. 
The logistic model constructed here should be tested on data from a different time span and also on companies in different industries to check whether there are significant changes in the model's explanatory power and predictive abilities.

\section{References}

Altman E. I. (1968). Financial Ratios, Discriminant Analysis and the Prediction of Corporate Bankruptcy. Journal of Finance, 23(4), 589-609

Adiana NHA, Halim A, Ahmad H, \& Rohani M. R. (2008). Predicting Corporate Failure of Malaysia's Listed Companies: Comparing Multiple Discriminant Analysis, Logistic Regression and the Hazard Model. International Research Journal of Finance and Economics, 5,202-217

Aziz A, Emanuel D, Lawson G (1988). Bankruptcy prediction - and investigation of cash flow based models. Journal Management Studies, 25(5), 419-437 http://dx.doi.org/10.1111/j.1467-6486.1988.tb00708.x

Beaver W. H. (1966). Financial Ratios as Predictors of Failure. Journal of Account Research, 4, 71-111. http://dx.doi.org/10.2307/2490171

Black F, \& Scholes M. (1973). The pricing of options and corporate liabilities. Journal of Political Economy, 7, 637-654. http://dx.doi.org/10.1086/260062

Casey CJ, \& Bartczak N. J. (1985). Using operating cash flow data to predict financial distress: Some extensions. Journal of Accounting Research, 23(1), 384- 401. http://dx.doi.org/10.2307/2490926

Deakin E. B. (1972). A discriminant analysis of predictors of business failure. Journal of Accounting Research, 10(1), 167-179. http://dx.doi.org/10.2307/2490225

Dorsey, RE, Edminster JO, \& Johnson JD. (1995). Bankruptcy prediction using artificial neural systems. The University of Mississippi, School of Business. Retrieved 10 May, 2006 from:http://www.ru.lv/ peter/ida/bankruptcy/bancruptcynn.pdf

Flagg JC, Giroux GA, \& Wiggins CE. (1991). Predicting corporate bankruptcy using failing firms. Review of Financial Economics, 1(1), 67-78.

Frydman H, Altman EI, \& Kao D L. (1985.) Introducing recursive partitioning for financial classification: The case of financial distress. Journal of Finance, 40(1), 269-291

Gardiner MA. (1995). Financial Ratios Definitions Reviewed. Management Accounting, 73(8), 32 .

Gepp A, Kumar K (2008) The Role of Survival Analysis in Financial Distress Predictions. Interntional Research Journal of Financial Economics, 16:13-34

Gilbert L, Menon K, \& Schwartz KB. (1990). Predicting bankruptcy for firms in financial distress. Journal of Business, Finance and Accounting, 17(1), 161-171. http://dx.doi.org/10.1111/j.1468-5957.1990.tb00555.x 
Gombola M. J., \& Ketz J. E. (1983). A note on cash flow and classification patterns of financial ratios. Accounting Review, 42(1), 105-114.

Green D. (1978). To predict failure. Management Accounting, July, 39-45

Hossari G, \& Rahman S. (2005). A Comprehensive Formal Ranking of the Popularity of Financial Ratios in Multivariate Modeling of Corporate Collapse. Journal of American Academy of Business, Cambridge, Mar, 321-327,

Inman M. K. (1991). Z-Scores and Recent Events: Do They Shed Any Light?. Management Accounting, Jan, 44-48

Jones S, \& Hensher D. A. (2004) Predicting firm financial distress: A mixed logit Model. Accounting Review, 79(4), 1011-1038. http://dx.doi.org/10.2308/accr.2004.79.4.1011

Karels G, \& Prakash A. (1987). Multivariate normality and forecasting business Bankruptcy. Journal of Business, Finance and Accounting, 14(4), 573-593. http://dx.doi.org/10.1111/j.1468-5957.1987.tb00113.x

Koh HC, \& Killough L. N. (1990). The Use of Discriminant Analysis in the Assessment of the Going Concern Status of an Audit Client. Journal of Business, Finance and Accounting, 17(2), 179-192. http://dx.doi.org/10.1111/j.1468-5957.1990.tb00556.x

Letza R, Kalupa L, \& Kowalski T. (2003) Predicting corporate failure: How useful are multi-discriminant analysis models?. The Poznan University of Economics Review, 3(2), 5-11.

Lev B. (1973). Decomposition Measures for Financial Analysis. Financial Management, Spring,56-63. http://dx.doi.org/10.2307/3665101

Li H, \& Sun J. (2010) Business failure prediction using hybrid case-based reasoning HCBR. Computers \& Operations Research, Jan, 137-151. http://dx.doi.org/10.1016/j.cor.2009.04.003

Lin L, \& Piesse J. (2004) The identification of corporate distress in UK industrials: A conditional probability analysis approach. Applied Financial Economics, 14, 73-82. http://dx.doi.org/10.1080/0960310042000176344

Low SW, Nor FM, \& Yatim P. (2001) Predicting corporate financial distress using the logit model:The case of Malaysia. Asian Academy of Management Journal, 6(1), 49-61.

Mohamed S, Li AJ, \& Sanda A. U. (2001). Predicting corporate failure in Malaysia: An application of the Logit Model to financial ratio analysis. Asian Academy of Management Journal, 6(1), 99-118.

Morris, R. (1998). Bankruptcy prediction models: Just how useful are they?. Credit Man, pp. 43-45. Retrieved 10 May 2006, http://findarticles.com/p/articles/miqa5308/is199805/ai n21421946 
Mossman CE, Bell GG, Swartz LM, \& Turtle H. (1998). An empirical comparison of bankruptcy models. Financial Review, 33(2), 35-53. http://dx.doi.org/10.1111/j.1540-6288.1998.tb01367.x

Norusis M. J. (1994). SPSS Professional Statistics, 6.1, SPSS Inc. Chicago

Ohlson J. A. (1980). Financial Ratios and the Probabilistic Prediction of Bankruptcy. Journal of Accounting Research, Spring, 109-131. http://dx.doi.org/10.2307/2490395

Poston K.M., Harmon W. K., \& Gramlich J. D. (1994). A test of financial ratios as predictors of turnaround versus failure among financially distressed firms. Journal of Applied Business Research, 10(1), 41-52.

Pramodh C, \& Ravi V. (2007). Modified Great Deluge Algorithm based Auto Associative Neural Network for Bankruptcy Prediction in Banks. International Journal of Computational Intelligence Research, 3(4), 363-370. http://dx.doi.org/10.5019/j.ijcir.2007.117

Shivaswamy M, \& Holban Jr J.P. (1993). A behavioral analysis of financial ratios. The Mid Atlantic Journal of Business, 29(1), 7-23.

Shumway T. (2001). Forecasting bankruptcy more accurately: A simple hazard model. Journal of Business, 74, 101-124. http://dx.doi.org/10.1086/209665

Wood D, \& Piesse J. (1987). The Information Value of MDA Based Financial Indicators. Journal of Finance and Accounting, 14(1), 27-38.

Zulkarnain M.S., Mohamad A.A.H., Annuar M. N., \& Zainal A. M. (2001) Forecasting corporate failure in Malaysian industrial sector firms. Asian Academy of Management Journal, 6(1), 15-30. 